\title{
The Difficulties Encounter (ESP) Students in Using English Prepositions of Time
}

\author{
Abdelrazig Abdelghani Mahil Ibrahim* \\ (ESP)Lecturer - Posha Academy-Kingdom of Saudi Arabia \\ *Corresponding Author: Abdelrazig Abdelghani Mahil Ibrahim, (ESP)Lecturer - Posha Academy- \\ Kingdom of Saudi Arabia
}

\begin{abstract}
This study aims at investigating the problems encounter (ESP) students in using English prepositions of time (on - at - in). It also sheds light on the causes stand behind these problems. The study adopted a descriptive, analytical and quasi-experimental method. The sample of the study consisted of (40) students at Posha Academe in the first semester of the academic year 2017 - 2018. To collect data, the researcher employed a test. The study used (SPSS) to analyze the data. The findings revealed that the majority of the students encounter problems in using prepositions of time.

Based on the findings the study offers the following recommendations:

Curricula designers should pay more attention for prepositions in designing syllabuses .Teachers should deliver intensive exercises to students concerning prepositions. Students should give more attention to English in general and prepositions in particular. Teacher should employ effective teaching techniques to help students improve in this area.
\end{abstract}

Keywords: investigate, encounter, prepositions of place, (ESP) students.

\section{INTRODUCTION}

Learning a language necessarily means learning the grammar of that language. Learning grammar must begin with a working knowledge of its components, meaning learning about the parts of speech and how they fit together into sentences. In the process, students are enabled to distinguish a preposition from an adverb or a phrase from a clause. This way, the students will be guided in expressing their thoughts and ideas in writing or in oral form not only correctly but with variety, elegance and efficiency.

English prepositions are difficult for any EFL learner because he/she usually relates them to his/her own mother tongue prepositional system. The difficulty is also caused by the difference in number, meaning and usage of the prepositions in the mother tongue and in the EFL.

In learning English prepositions, Arab students try to relate them to the smaller number of Arabic ones and to the Arabic prepositional system. Although Arabic and English prepositions have some characteristics in common, they differ in both number and usage.

It is a fact that not every Arabic preposition has a definite English equivalent and vice-versa. On the other hand, not every English or Arabic preposition has a definite usage and meaning, indicating only time or space or following a certain word.

Another factor to be considered is the textbooks and methods used by teachers who are not familiar with the predictable errors the students will make or with the causes behind them.

This study focuses on the use of prepositions of time which is a problem among many Saudi learners and identifies the errors committed in the use of prepositions of time, the reasons why the students commit such errors and in the process suggests steps by which both teachers and students will find it easy to use prepositions of time without fear of committing errors.

\subsection{Definition of Prepositions}

A preposition is a word that shows relationships between words in the sentence. According to Yates $\mathbf{J}$ (1999, p.5), "The word "preposition" has a straightforward definition: a word placed before a noun or 
pronoun to define its relationship with another word in the sentence." It is worth mentioning that "The word preposition is divided into two syllables pre/position" (Shehata M.2003, p.214)

Walker (1982, p.123) considers preposition is a word that shows a relationship between a noun or pronoun and other part of sentence. Also Cowan (1983:281) when regarded preposition as a group of word that indicate relationship between the object of preposition and some other words in the sentence. Her words indicated the important function of preposition in the sentence: such as they use nouns and pronouns to create phrase, and they linked these phrases to the rest of sentence. The writer illustrated by mentioning that the functions such as indicators of time, place, cause, manner, agency association, or other relationships. In addition to, usually preposition occur in phrase that function as adverbs or adjective .other definition of preposition which stated by (Wren \&Martin, 1999, p.106 as cited in Hassan, 2016) are considered a preposition as a word place before a noun or pronoun to show in what relation the person or thing denoted by its stands in regard of something else.

Stageberg (1981,p. 169), states that prepositions are words like of, in, on, at and to which are usually followed by a noun, noun phrase, personal pronoun, or noun substitute called the object of the preposition. The unit of preposition plus its object is called a prepositional phrase as in the following examples:

- George sat between the two deans.

- George jumps on it.

- George went from this to that.

According to Crystal (2003, pp. 165, 213), expressing a relation of meaning between two parts of a sentence, a preposition most often shows how the two parts are related in space or time:

- We sat on the bench.

- They left at three.

\subsection{Types of prepositions}

Kinds of prepositions contribute in avoiding confusion between preposition and other grammatical elements in the sentence. For example there are many words used sometime as adverb and sometime as preposition the only difference is that preposition govern a noun or a pronoun while the adverb does not .The following examples show that;

-Go, and run about. (Adverb)

-Don't loiter about the street. (Preposition)

According to (Wren \& Martin, 1999, p.108 as cited in Hassan) preposition can be classified into four main categories with regard to the number of syllables that comprise the preposition or the number of words such as; simple prepositions are words like in, on, at and for. Compound prepositions which are words formed either by prefixing a preposition ( $\mathrm{a}=$ no and be=by) for instance; about, along, around, before, behind and below, or by double in a preposition like without, within, outside of, out of and from behind. Participle prepositions are words such as concerning, notwithstanding and pending. Phrase prepositions are group of word used with the force of single preposition like because of, by means of, in case of and in order to.

\subsection{What makes learning prepositions so difficult?}

This challenge can be attributed to several factors. First, prepositions are generally polysemous. Polysemy is "a semantic characteristic of words that have multiple meanings" (Koffi, 2010, p. 299). Essentially, the majority of prepositions in English have a variety of meanings depending on context. Thus, learners often become frustrated when trying to determine prepositional meanings and when trying to use them appropriately (Koffi, 2010, p. 299). Second, as Lam (2009) points out, prepositions can be difficult to recognize, particularly in oral speech, because they typically contain very few syllables. Many English prepositions are monosyllabic, such as on, for, or to. As a result, language learners may not be able to recognize prepositions in rapid, naturally occurring speech. Moreover, the use of prepositions in context varies greatly from one language to another, often causing negative syntactic transfer. The same prepositions can carry vastly different meanings in various languages. For instance, a native speaker of Spanish would have difficulties translating the preposition por into 
English, since it can be "expressed in English by the prepositions for, though, by, and during" (Lam, 2009 , p. 2). Therefore, learners cannot depend on prepositional knowledge from their first language. If learners do make "assumptions of semantic equivalence between the first and second languages", it often results in prepositional errors (Lam, 2009, p. 3). Lastly, the sheer number of prepositions in the English language also contributes to their difficulty. English has 60 to 70 prepositions; a higher number than most other languages (Koffi, 2010, p. 297).

English prepositions are certainly one of the most difficult aspects of English language for non-native speakers to learn, Coleman $(2003$, p.43) states, that too often native speakers themselves are not conscious of how prepositions are used in English. Lakoff (1978) argues that prepositions are likely to have a relatively small number of related literal meaning. Some of the literal meanings a preposition especially it's prototypical meaning, are extended by metaphor to create another relatively small set of related meanings. (Diab, N ,1998,cited in Khayal, 2011) states that prepositions pose a great difficulty for Arab learners of English since there are various prepositions in English that have the same function for example the prepositions "at" and "on" as in: a duty at night / a program on the TV. However, when students are not sure which prepositions to use in a certain phrase, they often resort to a possible equivalence in their mother tongue, giving a literal translation of the Arabic preposition into English.

\subsection{Approaches to Teach Prepositions}

\section{a) Traditional Approach}

The traditional method of teaching prepositions is through explicit grammar instruction. Students focus on learning prepositions individually within context, with no further expansion (Lam, 2009, p. $3)$. This approach assumes that there is no predictability in the use of prepositions, and that they must simply be learned context by context (Lam, 2009, p. 3). Lam's (2009) study revealed that students who were taught using this traditional method had little confidence in their ability to properly use prepositions, and had minimal retention rates. As Lam (2009, p.3) elaborates, "Trying to remember a list of individual, unrelated uses is hardly conducive to increasing learners' understanding of how the prepositions are actually used and why the samepreposition can express a wide range of meanings". Thus, it is apparent that language instructors must explore more explanatory methods of teaching prepositions.

\section{b) The Proto Type Approach}

The approach taken is subsumed within Lakoff's application of prototype theory to linguistics (as formulated most prominently by, for example, Rosch 1978). A key argument about prepositions is that each one is likely to have a relatively small number of related literal meanings, among which tendency is for one to be psychologically 'prototypical'. An additional contention is that some of the literal meanings of a preposition, especially its prototypical meaning, are extended by metaphor to create another relatively small set of related meanings.

According to Lindstromberg, (1991, p.228), "the proto type theory contends that the polysemous of prepositions can be explained through analysis of proto type meanings all non-proto typical meanings are thought to be related to the proto type often through metaphorical extension. Looking again at the prepositions on Lindstromberg (1991) explain that non- proto typical meanings like come on can be understood by extending the proto typical meanings. This means that teachers must first teach the proto typical meanings, often through the use of total physical reports (TPR), and only then began to branch out to more abstract meanings. To extend the semantic mapping even further, comparison and contrast to other prepositions can be useful.

\subsection{Previous Studies conducted in the area of prepositions}

Study (1)

This is an M.A study. The title of this study is "Investigating Difficulties Encountering MA Students of Linguistics in Using Prepositions in a Written Text" It carried out by Anass Abdelwhab Gassmallah in (2017) at Sudan University of Science and Technology - Sudan. This study aimed at investigating the problems that MA students of linguistics batch 7 are encountered by using and understanding prepositions. The researcher adopted a descriptive analytical method, which followed a quantitative analysis. A test was used as a tool for data collection, the sample of the study consists of 30 students 
drawn from MA program in Linguistics, Sudan University of Science and Technology, Graduate Studies. The study comes out with the results that MA students of linguistics face problems in using prepositions, MA students of linguistics fail to use suitable prepositions to fill in the blanks which make the context not cohesive and MA students of linguistics are poor in identification different types of prepositions. At the end of the study the researcher presented some recommendations. These recommendations focus on paying attention to the use prepositions when designing syllabuses, students should do more practice in using prepositions.

Study (2)

This study conducted by Aidross in (2008) in Shandi University - Northern Sudan .The title of this study is "Error Analysis of the use of prepositions in English writing skill". This study aims to analyzing the of the use of some prepositions such as (among, between, beside, by and with) in writing skill as well as identifying the actual reasons behind those difficulties and finding the suitable solution for them. The study applied analytical and descriptive method, the study population includes teachers and students department of English Language at University of Shendi, Faculty of arts. The sample of the study includes 10 teachers and 28 students, the study tools are questionnaire and test. The researcher used the percentage for analyzing data and come up with the following results: theseprepositions are problematic, students assume that prepositions are easy and prepositions aren't given enough efforts in teaching, also recommendations come out as follow: prepositions should be included in the syllabus of the university, teachers should give enough effort for teaching prepositions and students should be motivated and be aware of learning prepositions.

Study (3)

This study is a research paper. The title of it is "Writing Difficulties in Prepositions of Place Encountered by Albaha University Students' at Preparatory Year Program". It was written by Abualzain at Baha University. It was published in International Journal on Studies in English Language and Literature" in (2017). The study attempts to explore the writing difficulties in prepositions of place (at, in and on) encountered by Albaha university students' at preparatory year program. It also sheds light on the causes stand behind these difficulties. Fifty students at Albaha University enrolling in the preparatory year program were chosen randomly. The study used attest and a questionnaire as tools to collect data. The findings revealed the deficiency performance of the students in using the prepositions of place in a proper way. The teachers attributed this failure to the interference of the mother tongue and the carelessness of the students.

\section{SigNifiCANCE OF THE STUdY}

The significance of this study will be of great value for the following:

1. English language teachers at tertiary level.

2. Planners and designers of English language syllabi.

3. Researchers in the area of English language teaching as a foreign language.

4. Students of English as a foreign language

\section{STATEMENT OF THE PROBLEM}

Based on his experience as an English instructor for more than fifteen, the researcher has noticed that there is a lack of research material on this topic, particularly the prepositions of time and this is the reason that encouraged the researcher to select this subject. Prepositions are one of the most difficult aspects of English for EFL Learners. By analyzing their errors one could build up a picture of the features of the language which cause some learning problems. When such problems are understood in the right perspective, remedial measures could be thought of. Hence, the present study focuses on the use of prepositions of time and students' errors in such uses.

\section{OBJECTIVES OF THE STUDY}

To investigate the actual reasons behind the problems that facing (ESP) students in using English prepositions of time and recommend ways so as to solve the problems.

\section{QUESTIONS OF THE STUDY}

1. Do (ESP) students encounter problems in using prepositions of time?

2. How can those problems be tackled by teachers? 


\section{LIMITATIONS OF THE STUDY}

This study will be limited to level (2) students at Projects Occupational Safety High Academy (Posha) in the academic year 20172018.

\section{MeThodology}

\subsection{Study Design}

This is an analytical study and its objective is to investigate the actual reasons behind the problems that facing (ESP) students in using English prepositions of time.

\subsection{Population of the study}

The population of the current study consists of all students at Projects Occupational Safety High Academy (Posha) who are enrolled in Higher Occupational Safety and Health Diploma Program in the first semester of the academic year 2017/2018 in Riyadh city.

\subsection{Sample of the study}

The sample used for this study is limited to level (2) students .The total number is (40) students chosen randomly among the students. The students' mother tongue is Arabic and their ages range between nineteen and twenty-four.

\subsection{Data collection}

This study aimed at investigating the actual reasons behind the problems that facing (ESP) students in using English prepositions of time and recommend ways so as to solve the problems. Therefore, the following two questions as an attempt to investigate and solve this problem were raised

1. Do (ESP) students encounter problems in using prepositions of time?

2. How can those problems be tackled by teachers?

\subsection{Instruments of the study}

In order to collect reliable data, a test was employed in this study.

Grabe(2009), believes that gap-filling is a more beneficial question type in measuring the knowledge of some target structures such as prepositions.

The test comprises fourteen statements about the prepositions of time (on - at - in). The students were asked to write the correct preposition in its correct place. The SPSS program will be used to analysis data.

\subsection{Validity of the test}

In order to ensure the validity of the test was shown to a panel of two university professors and two EFL teachers. The final form of the test was drawn out after taking their comments, opinions and advices into consideration.

\subsection{Internal Consistency and reliability of the test}

Reliability is one of the most important elements of test quality. It has to do with the consistency, or reproducibility, or an examinee's performance on the test. Davies (in Alderson \& Banerjee, 2002) argues that if reliability is maximized it may be at the expense of validity, and if validity is maximized, then it might be at the expense of reliability when it comes to language testing.

Cronbach's $\alpha$ was computed for ESP test which revealed that the tool was stable $(\alpha=.768)$ which indicates that the test can be a reliable tool to measure the construct consistently.(See Table1).

\section{DisCUSSION}

In order to the test sentences were analyzed using False (' 0 ' for the wrong answer) and True (' 1 ' for the correct answer) higher score indicate more Knowledge and awareness of using English prepositions of time.

As shown in table (1) for the use of (at) in sentence No.6, 1, 5 and 8 revealed that $65.0 \%$, of the students answered the question correctly, while $35.0 \%$ do not. For the use of (at) in sentence No.1, $62.5 \%$ of the students answered the question correctly, while $37.5 \%$ do not. Similarly, in the use of (at) in sentence No.5, 62.5\% of the students answered the question correctly, while $37.5 \%$ do not, 
while in the use of (at) in sentence No.8, $60.0 \%$ of the students answered the question correctly, while $40.0 \%$ do not. And for the error occurs in questions No. 2 and 3 in the use of preposition "at", the students found difficulty with this preposition when used in the sentence for the reason that since (at) talks about a relative position and not an accurate position.

These results showed that the majority of the students did not encounter difficulty in using proposition regarding exact time, so they used the required preposition properly.

On the other hand, students faces remarkable difficulty in answering questions No. 2, 3 and 4 correctly. Indicting that they have difficulty on the subject of using propositions in a sentences regarding particular place, days of the week, parts of the day and combination between days and parts of the day i.e. (I have a meeting Sunday morning). Also, the students face difficulty on the subject of using propositions (use of "on" and "in") in a sentences regarding meals time and months i.e. (sentences No. 9, 10 and 13) respectively. It's worth mentioning that in the use of the preposition "on", the students found difficulty to answer correctly, they got confused with (on) for the reason that (on) can be used with days and dates.

Table1. Students' correct and wrong answers regarding the test $(n=40)$

\begin{tabular}{|c|c|c|c|c|}
\hline \multirow{2}{*}{$\begin{array}{l}\text { Stat. } \\
\text { No }\end{array}$} & \multirow[b]{2}{*}{ Test sentences } & \multirow{2}{*}{$\begin{array}{l}\text { Correct } \\
\text { Prep. }\end{array}$} & \multicolumn{2}{|l|}{ Test scores } \\
\hline & & & $\begin{array}{l}\text { True answers } \\
\mathrm{N}(\%)\end{array}$ & $\begin{array}{l}\text { False answers } \\
\mathbf{N}(\%)\end{array}$ \\
\hline 1 & The stars shine ___ night. & at & $25(62.5)$ & $15(37.5)$ \\
\hline 2 & He's not at home ___ present. & at & $12(30.0)$ & $28(70.0)$ \\
\hline 3 & I usually don't work ___ the weekend. & at & $13(32.5)$ & $27(67.5)$ \\
\hline 4 & I have a meeting ___ Sunday morning. & on & $14(35.0)$ & $26(65.0)$ \\
\hline 5 & The shops close ___ midnight. & at & $25(62.5)$ & $15(37.5)$ \\
\hline 6 & He goes to bed ___ ten o'clock every day. & at & $26(65.0)$ & $14(35.0)$ \\
\hline 7 & They have a little snack ___ the evening. & in & $18(45.0)$ & $22(55.0)$ \\
\hline 8 & She gets up __ five o'clock. & at & $24(60.0)$ & $16(40.0)$ \\
\hline 9 & Naif went home ___ lunchtime. & at & $20(50.0)$ & $20(50.0)$ \\
\hline 10 & In England, it often snows ___ December. & in & $19(47.5)$ & $21(52.5)$ \\
\hline 11 & Do you play football ___ the afternoon? & in & $21(52.5)$ & $19(47.5)$ \\
\hline 12 & summer the weather is too hot. & in & $21(52.5)$ & $19(47.5)$ \\
\hline 13 & She was born ___ the 2nd of January. & on & $19(47.5)$ & $21(52.5)$ \\
\hline 14 & They sometimes visit me ___ Friday & on & $23(57.5)$ & $17(42.5)$ \\
\hline & & & $\% 50$ & $\% 50$ \\
\hline
\end{tabular}

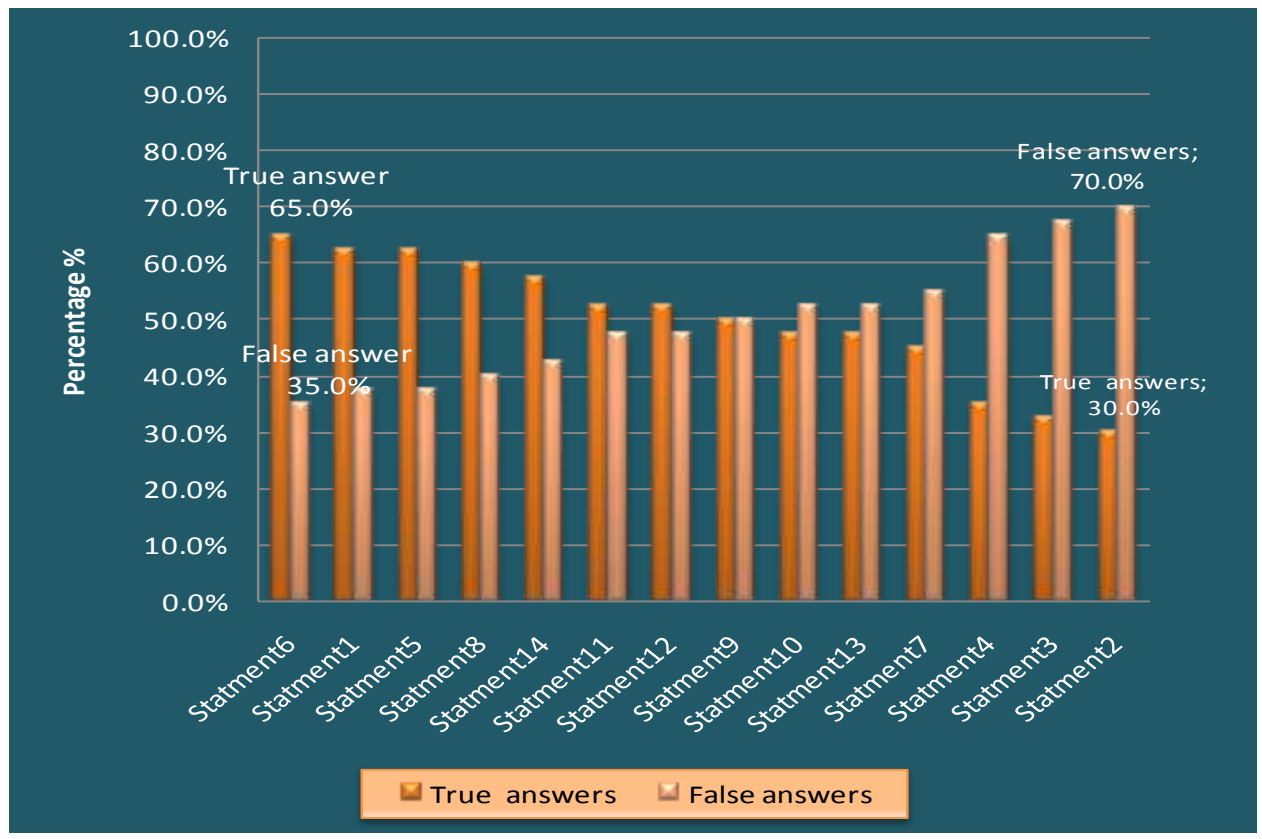




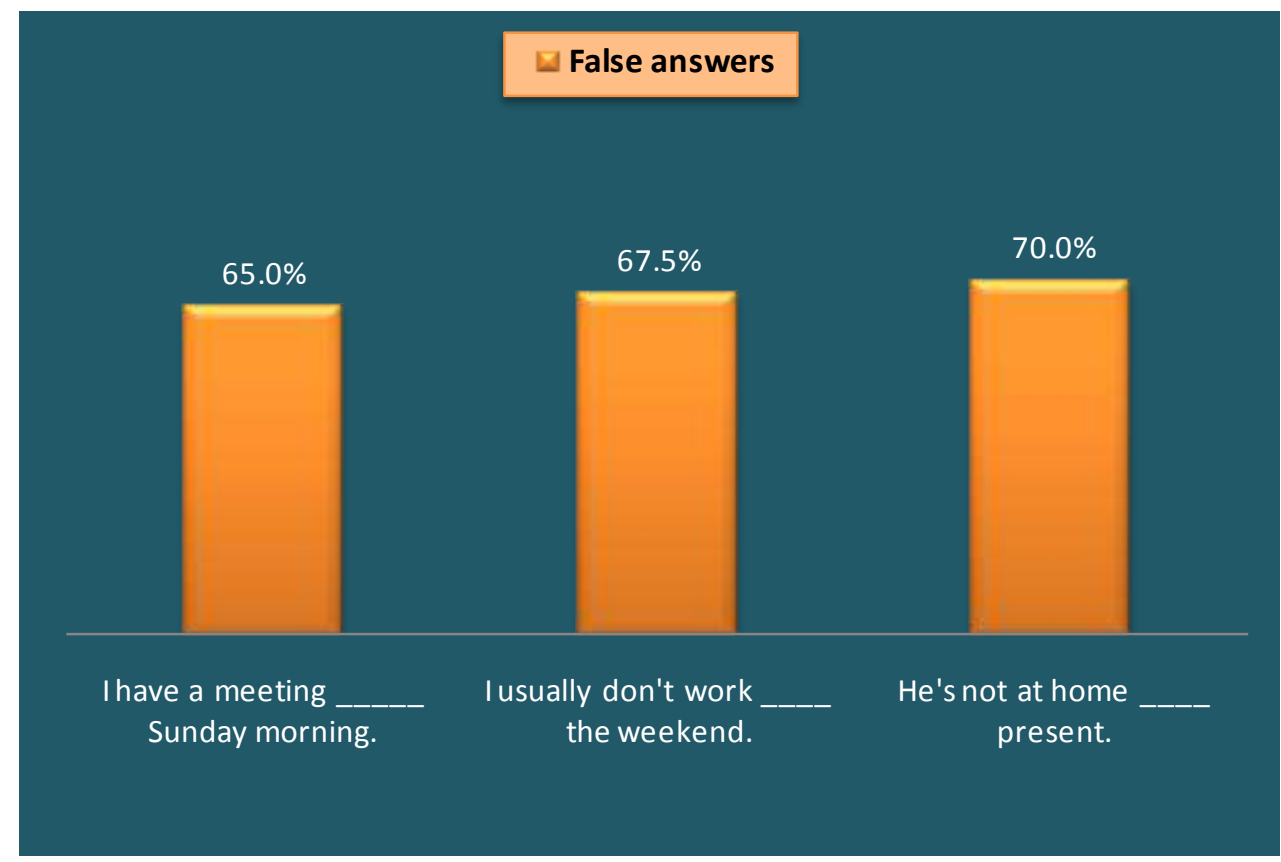

Top false answers (statements 4, 3 and 2) respectively from the left)

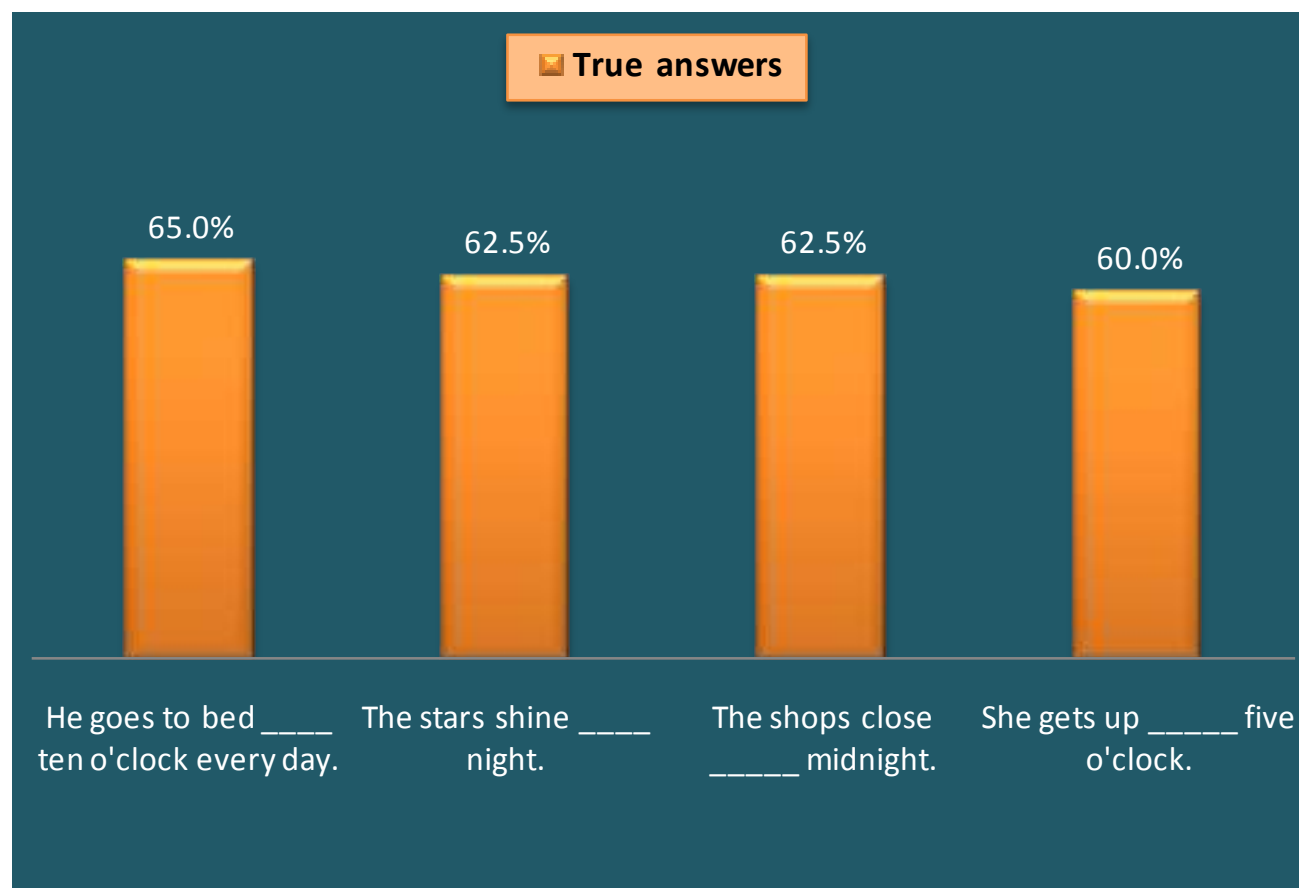

Top true answers (statements 6, 1, 5 and 8) respectively from the left

Table2. Students' Achievement regarding the preposition test $(n=40)$

\begin{tabular}{|c|c|}
\hline Test grades & TOTAL Score \\
\hline Fail (below average ) & $\mathbf{2 2}$ \\
& $(55.0 \%)$ \\
\hline Pass (50-74) & 10 \\
& $(25.0 \%)$ \\
\hline Good (75-100) & 8 \\
& $(20.0 \%)$ \\
\hline Total & $\mathbf{4 0}$ \\
& $(100 \%)$ \\
\hline
\end{tabular}




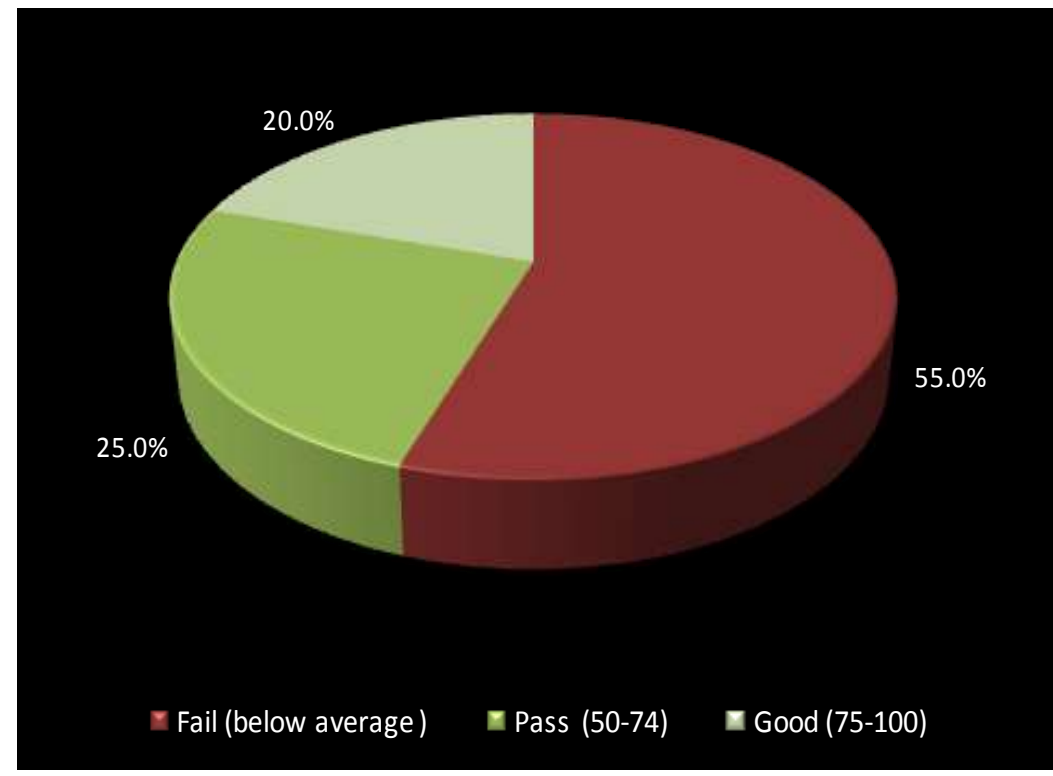

As shown in table (2) and the figure above, that most of the students involved in this study failed to use the preposition "at", "in" and "on" and the preposition mistakes of time are the mainly common error. So, the majority of the students encounter problems in using prepositions of time.

These results can be considered as the answer of the current study research question which said that: (Do (ESP) students encounter problems in using prepositions of time?)

Finally, since the preposition "at", "in" and "on" are among the prepositions that are commonly employed by English language speakers, the teachers can tackle preposition problems by the following strategies:

- Asking students to detect the pattern on their own to be able to learn and recognize the typical prepositional uses better

- Encouraging student to find out the different grammatical rules by themselves to develop their sensitivity to the language

- And the role of the students in this issue that they should stay away from turning to the mother tongue when answering prepositions exercises.

\section{CONCLUSION AND RECOMMENDATIONS}

The purpose of this study is to investigate the problems encounter (ESP) students in using English prepositions of time (on - at - in). It also sheds light on the causes stand behind these problems. A questionnaire was used as a tool to collect data.

In the light of the results of this study, the findings revealed that the majority of the students encounter problems in using prepositions of time. Based on the findings the study offers the following recommendations:

1. Curricula designers should pay more attention for prepositions in designing syllabuses.

2. Teachers should deliver intensive exercises to students concerning prepositions.

3. Students should give more attention to English in general and prepositions in particular.

4. Teacher should employ effective teaching techniques to help students improve in the area of prepositions.

\section{REFERENCES}

[1] Aidaroos, H.M. (2008) Error Analysis of the use Prepositions in English writing Skill, Unpublished M.A. Thesis Shandi University.

[2] Alderson, C. J., \& Banerjee, J. (2001). Language testing and assessment (Part 1). Language Teaching, 34, pp. 213-236 doi: 10.1017/S0261444800014464 Coleman, S. (2003). English Prepositions. Cambridge: Cambridge University press. 
[3] Cowan, E. (1982).Writing. Brief edition scott, foresman and company. U.S.A.

[4] Crystal, D. (2003): The Cambridge Encyclopedia of the English Language. 2ndEdition.Cambridge. Cambridge University Press. 2003, p.165, 21.In Philology and Cultural Studies. Vol. 6(55) No.1 - 2013 Retrieved from: http://www.diacronia.ro/ro/indexing/details/A20106/pdf

[5] Gassmallah, A., A. (2017).Investigating Difficulties Encountering MA Students of Linguistics in Using Prepositions in a Written Text. Unpublished M.A. Thesis. Sudan University of Science and Technology

[6] Grabe, W. (2009).Reading in a second language: Moving from a theory to Practice. New York: Cambridge University Press.

[7] Hassan, E. R. (2016).Investigating EFL Learners' Problems of Using and understanding Prepositions. Unpublished A.M. Thesis. Sudan University of Science \&Technology.

[8] Ibrahim, Y., O. (2017).Writing Difficulties in Prepositions of Place Encountered by Albaha University Students' at Preparatory Year Program. In International Journal on Studies in English Language and Literature. Volume 5, Issue 5, May 2017, PP 1-8.Reterived from https://www.arcjournals.org/pdfs/ijsell/early-view/1.pdf

[9] Khayal, A., S. (2011).Problems of English Prepositions of Time Encountered by Libyan Secondary Stage Students. In University of Asmaria Journal.Vol.23, 2011.Reterived from: http://www.asmarya.edu.ly/journal2/wpcontent/uploads/2017/03/16Problems-of-English.pdf

[10] Koffi, E. (2010). Applied English syntax: Foundations for word, phrase, and sentence analysis. Dubuque, Iowa: Kendall Hunt Publishing Company.

[11] Lakoff, J. (1978). Principles of Language Learning and Teaching English. Chicago; Chicago University press.

[12] Lam, Y. (2009). Applying cognitive linguistics to teaching the Spanish prepositions por and para. In Linguistic Portfolios.Vol.12012,Art.14.Retrievedfrom:

http://repository.stcloudstate.edu/cgi/viewcontent.cgi?article $=1012 \&$ context $=$ stcloud_ling

[13] Lindstromberg, S. 1991. 'Reaching prepositions'. In International Journal on Studies in English Language and Literature. Volume 5, Issue 5, May 2017, PP 1-8.Reterived from: https://www.arcjournals.org/pdfs/ijsell/earlyview/l.pdf

[14] Rosch, E. (1978). 'Principles of categorization' in E. Rosch and B. Lloyd (eds.) Cognition and Categorization. New York: Lawrence Erlbaum.

[15] Shehata M. (2003), Grammar, Alexandria, Dar Ebnkhaldoon. Stageberg, N. C. (1981): An Introductory English Grammar. 4th Edition. New York. Holt, Rinehart and Winston, Inc. Retrieved from: http://www.diacronia.ro/ro/indexing/details/A20106/pdf

[16] Walker, B.L. (1982).Basic English Grammar. Baltimore, Maryland .USA Yates, J. (1999), the ins and outs of prepositions, New York Barron's Educational Series

\section{AUTHOR'S BIOGRAPHY}

Dr. Abdelrazig Abdelgani Mahil, got his Ph.D. in English Language from Alzaiem Alazhari University in (2017). He has an M.A in General Translation from University of Juba (2010) He alsogot a Post graduate Diploma in General Translation from University of Juba (2008). He awarded a bachelor (2004) and Intermediate Diploma degree in (1998) in Sharia'a and Law from Omdurman Islamic University. In addition to that he got an Intermediate Diploma in English Language from Nelain University in (2002) .He attended many courses and workshops in the field of English Language Teaching. He worked as an English teacher in Sudan Schools .He also worked as (ESP) Lecturer in Preparatory Year Program in several Saudi Universities. Currently he is (ESP) Lecturer at Posha Academy - Saudi Arabia - Riyadh City. He has published many research papers in different journals in the field of English Language Teaching and Translation.

Citation: Abdelrazig Abdelghani Mahil Ibrahim. "The Difficulties Encounter (ESP) Students in Using English Prepositions of Time" International Journal of Humanities Social Sciences and Education (IJHSSE), vol 4, no. 11, 2017, pp. 214-222. doi: http://dx.doi.org/10.20431/2349-0381.0411025.

Copyright: (0) 2017 Authors. This is an open-access article distributed under the terms of the Creative Commons Attribution License, which permits unrestricted use, distribution, and reproduction in any medium, provided the original author and source are credited. 